\title{
CULTIVATING SELF-REGULATED LEARNING IN FLIPPED EFL COURSES: A MODEL FOR COURSE DESIGN
}

\author{
Ünal Çakıroğlu [cakiroglu@ktu.edu.tr], Karadeniz Technical University, Mücahit Öztürk \\ [mucahitozturk@aksaray.edu.tr], AksarayUniversity, Turkey
}

\begin{abstract}
Considerable effort has been invested in innovative learning practices in English Foreign Language courses (EFL) in universities. Flipped classroom model transforms passive listeners into active learners in school and home activities pace. Flipped classroom model and the foreign language teaching methods are student-centred learning environments in which students should have a certain level of self-regulated learning skills. The study suggest a model for flipped classroom implementations with regard to self-regulated learning strategies in order to keep students more active in the EFL courses. Students were allowed to apply goal setting and planning, rehearsing, help seeking, monitoring, testing, time management, organising, regulating and note taking strategies within the model in online and face to face sessions. We hope the suggested model can contribute to improve listening, reading, writing and speaking skills of students in EFL courses.
\end{abstract}

\section{Abstract in Turkish}

Ters yüz sınıf modeli okul ve ev etkinlikeri ile öğrencileri pasif dinleyicilerden aktif öğrenenlere dönüştürür. Ters yüz sınıf modeli ile yabancı dil öğretimi yöntemleri, öğrencilerin belirli düzeyde öz-düzenleyici öğrenme becerilerine sahip olması gerektirir. Bu çalışma, öğrencileri yabancı dil olarak İngilizce dersinde daha aktif tutmak için öz-düzenleyici öğrenme stratejilerini işe koşan ters yüz sınıf uygulamaları için bir model önermektedir. Model öğrencilerin amaç belirleme ve planlama, tekrarlama, yardım arama, izleme, test etme, zaman yönetimi, organizasyon, düzenleme ve not alma stratejilerinin çevrimiçi ve yüz yüze oturumlarda uygulamalarını içermektedir. Önerilen modelin yabancı dil olarak İngilizce dersinde öğrencilerin dinleme, okuma, yazma ve konuşma becerilerinin gelişmesine katkı sağlayacağı düşünülmektedir.

Keywords: flipped classroom; self-regulated learning strategies; EFL teaching; EFL skills; online learning

\section{Introduction}

Flipped Classroom implementations continue to grow and are playing an increasingly significant role in English Foreign Language (EFL) courses (Turan \& Akdag-Çimen, 2020). In flipped classroom model (FCM), it is aimed that the students should be more active in activities in online and Face to face learning (F2F) sessions. The FCM transforms passive listeners into active learners (Davies, Dean, \& Ball, 2013; Bergmann \& Sams, 2012). In some studies, it was found that the FCM has a positive contribution to academic achievement and engagement in the course compared to 
traditional face-to-face (F2F) instruction (Davies et al., 2013; Baepler, Walker, \& Driessen, 2014; McLaughin et al., 2014; Hung, 2015; Huang \& Hong, 2016; Butzler, 2016; Moos \& Bonde, 2016). In recent years, EFL has also been delivered through the framework of FCM and has provided positive learning outcomes on the development of foreign language skills (Chen-Hsieh, Wu, \& Marek, 2017; Zhonggen \& Guifang, 2016).

In the flipped EFL classroom, students should take responsibility to learn collaboratively, get instant feedback, and study with authentic situations, learn in depth and have more opportunities to interact with the instructor and classmates in the target language (Mehring, 2016). In order for students to carry out online learning and F2F learning activities together, they should have selfregulated learning skills in the flipped classroom model (Shih \& Huang, 2019). Self-regulated learning strategies are used to develop self-regulated learning skills. Zheng et al. (2020) revealed that students who cannot use SRL strategies may fail to understand and associate online content, which may negatively affect their performance in F2F activities. Allowing to use self-regulated learning strategies in F2F and online learning environments (OLE) while designing courses with FCM can positively contribute to students' performance (Butzler, 2016).

In this study, a design framework to apply self-regulated learning strategies is presented for flipping the EFL course. In this circumstance, this study deals with three basic concepts: flipped classroom model, self-regulation strategies and the skills presented in EFL course. In the following, the concepts are briefly explained.

\section{Flipped Classroom Model (FCM)}

In the face-to-face EFL instructions, an instructor spends much course time to explain concepts. As passive learners, students listen to the lesson and take notes during this time. At home, they work on the homework given to practice or reinforce conceptual knowledge. While students study with the content provided by the instructor at home, they can do student-centred activities in the F2F session (DeLozier \& Rhodes, 2017; Egbert, Herman, \& Lee 2015; Bergmann \& Sams, 2012). This means, when students come to the F2F sessions, deep learning may be emerged through discussions and evaluations, collaborative group work and questions that they set at home (Johnson, Adams, \& Cummins, 2012). Zainuddin and Halili (2016)argues that while students can access lower-level cognitive domain skills in Bloom's taxonomy such as remembering and understanding at home, they can obtain higher-level skills such as applying analysing, evaluating, and creating in a face-to-face learning environment.). Students can learn to benefit from the affordances of OLE and F2F learning sessions with the help of their peers or taking the guidance of their instructor (Shahnaz \& Hussain, 2016). Hamdan et al. (2013) describes four components of the FCM:

1. Flexible environment: It is the environment that provides flexible access without knowledge of time and space, including the different learning strategies.

2. Learning culture: It is a cultural change designed by student-centred active learning environments. 
3. Intentional content: Designing content that will allow students to develop their knowledge and skills and enable them to practice.

4. Professional Educator: Educators who are able to plan the activities and environment where the students are active and can support the students by providing feedback needed.

Both OLE and F2F sessions of the FCM should be designed within the framework of specific principles for the proper implementation of these four components in both out-off class and in class activities (Hamdan et al., 2013).

\section{Out-of Classroom Activities}

Students are prepared for a F2F lesson by studying course content out- of- class activities in the OLE sessions. By this way, students can learn at their own pace by taking responsibility for their own learning and engaging actively in their learning process. For this purpose, different OLEs can be used to provide effective sharing, interaction and communication for out-of-class activities. In addition, students can evaluate their own learning through online tests on the FCM (DeLozier \& Rhodes, 2017). Hereby, learning management systems such as Moodle, Khanacademy, Blackboard, Sakai and other tools such as Google docs, YouTube, Blogs, Wikis are used as OLEs for the FCM implementations (Elrayies, 2017; Al-Zahrani, 2015; Wanner \& Palmer, 2015). Course contents were designed in various formats such as video, screencast, simulation, animation, podcast, vodcast, PowerPoint presentations, reading notes and concept maps used in learning management systems (Huang \& Hong, 2016; Gilboy, Heinerichs, \& Pazzaglia, 2015; Kakosimos, 2015; Giannakos, Chorianopoulos, \& Chrisochoides, 2015; Love, Hodge, Grandgenett, \& Swift, 2014). However, videos are prominent in the out of classroom sessions of the FCMs. Video-creation programs such as Screencast-O-Matic, Camtasia Studio, and Adobe Presenter are used to create the video based contents and these can be published on video sharing sites such as Youtube, Panopto, Screencast, Google Drive (Coyne, Lee, \& Petrova, 2017; Özdamli \& Aşiksoy, 2016) or can also be delivered through the Learning Management Systems (LMS) used for FCM. The LMSs are suggested to allow the instructor to support students' knowledge construction.

\section{In-Classroom Activities}

In the FCM, it is aimed to construct knowledge and gain students' high level of thinking skills by using active learning strategies such as problem solving, discussion, collaboration group work, brain storming and working on projects in the F2Fsessions (DeLozier \& Rhodes, 2017). In the F2F sessions, students should complete activities out of classroom; thus, instructor provides feedback to the students about the activities to support them (Roehl, Reddy, \& Shannon, 2013). Students may also be given additional time to complete the activities. On the other hand, question-and-answer activities, role playing and self or peer evaluation activities can be done in the F2F learning environment (Shahnaz \& Hussain, 2016). Thus, students can monitor and complete their own learning process and they can take responsibility. Figure 1 summarises a typical implementation of the FCM. 


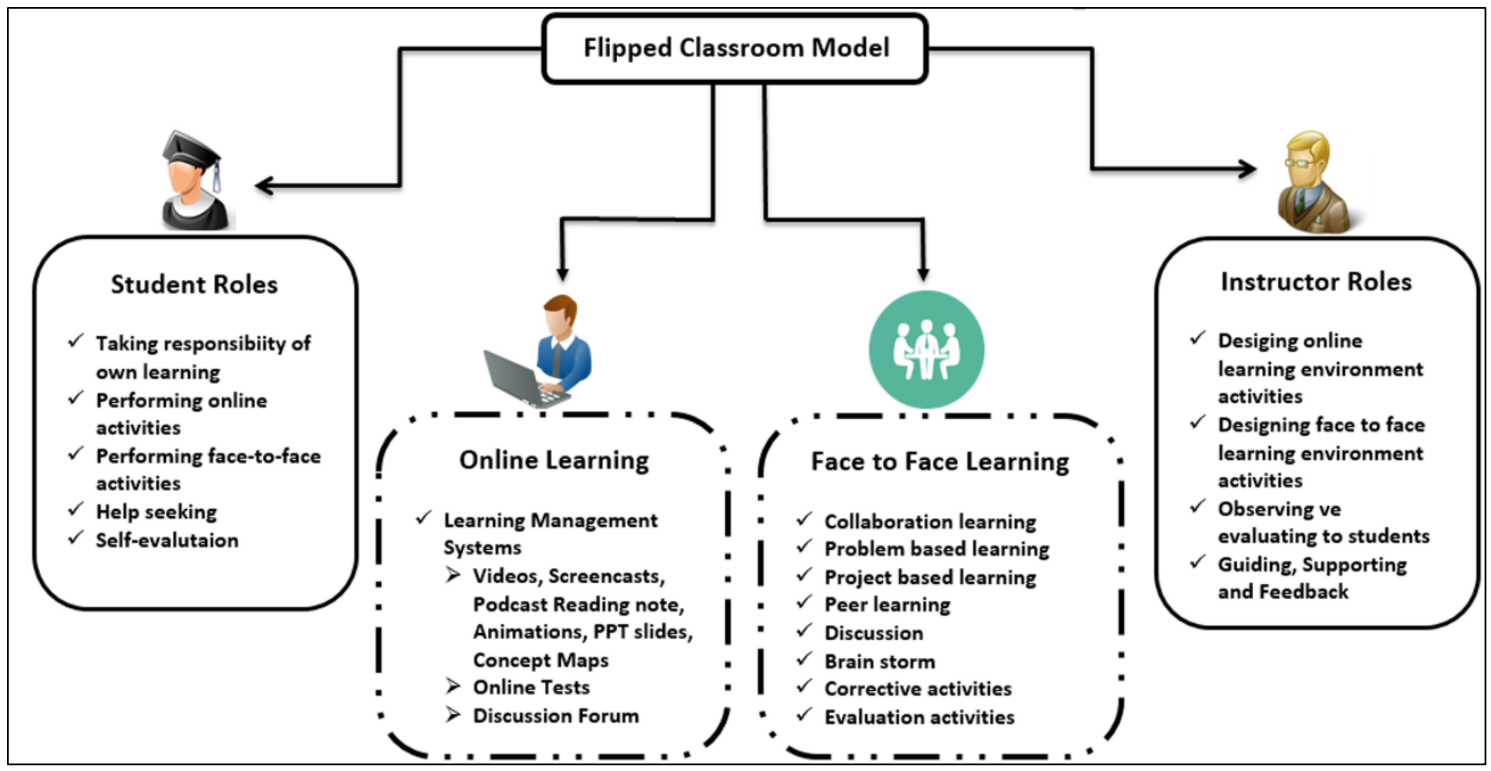

Figure 1. Flipped classroom model

During the FCM applications both in OLE and F2F sessions, students are required to take their own learning responsibilities both inside and outside of the classroom, while they perform activities in the guidance of the teacher. In the OLE session of FCM, the content should be designed to attract the attention of the students (Hotle \& Garrow, 2015). In addition, instant feedback is required to students in this session and the use of assessment tools is necessary to evaluate students' performance in an OLE. At this point, the instructor should make the necessary regulations for students with low self-regulated learning skills to engage in activities and take responsibility for learning. Instructor can conduct online test and self-assessment activities for students to evaluate their knowledge of the subject to be learned ( $\mathrm{Ng}, 2018)$. In addition, peer discussions, group presentations and quizzes can be made to help students complete their deficiencies (Shih \& Huang, 2019). Instructor should also support and monitor their students with their explanations on the subject (Lai \& Hwang, 2016).

Since the applications of FCM are growing, the potential of the FCM is evaluated in different disciplines (Zainuddin \& Halili, 2016). In recent years, the FCM has begun to be used in different types of class settings. One important area of FCM applications is EFL courses (Djamàa, 2020; Egbert et al., 2015; Engin \& Donanci, 2016; Huang \& Hong, 2016; Mehring, 2016; Su Ping et al., 2020; Zhonggen \& Guifang, 2016).

\section{Flipping the EFL Course}

Educators are spending more efforts on teaching methods that will improve students' learning and increase their motivation, but traditional methods are still dominant in foreign language teaching (Chen-Hsieh et al., 2017). In this context, Egbert et al. (2015) points out that the limitations arising from time and space in traditional instruction are shortcomings in foreign language courses, especially in collaboration group activities, interaction with peer and teacher, and in speaking activities. Thus, Mehring (2016) suggest providing communication-based learning environments for keeping students active. In EFL teaching methods, there has been a shift from the teacher- 
centred learning environment to the student-centred communication-based learning environments (Mehring, 2016). Foreign language learning requires the use of new teaching methods as it involves social actions and require active participation of students (Alsowat, 2016). In the FCM, students can work with interactive contents prepared by the instructor in the OLE, while writing exercise with discussion forum, listening exercise with audio files. They can conduct speaking activities with discussion and collaboration group work in a F2F learning environment (Alsowat, 2016; Wu, Hsieh, \& Yang, 2017). The FCM can facilitate the learning of grammatical and sentence structures by providing students with unlimited access and repetition to various learning sources in the OLE, while improving their speaking and writing skills through discussion forums and chat rooms (Evseeva \& Solozhenko, 2015). In the face-to-face learning environment, some scholars claim that FCM can be effective in foreign language teaching because it can provide opportunities such as interaction with peer and instructor through collaborative group work (Egbert et al., 2015; Huang \& Hong, 2016).

In addition, innovative foreign language teaching methods also give the learner the responsibility to learn. Accordingly, in recent years, self-regulated learning skills have been examined as an important skill in foreign language teaching of the FCM designs. Thus, we hypothesize that the FCM can contribute to the development of language skills such as listening, reading, speaking, writing, grammar by offering communication based learning environment. In addition to taking responsibility for the learning process, the instructor's guidance in this process is related to selfregulated learning strategies (Lai \& Hwang, 2016).

\section{Flipped Classroom and Self-regulated Learning (SRL)}

SRL is considered as a process that helps students manage their thoughts, behaviours and emotions in order to successfully guide their learning experiences (Järvelä \& Järvenoja, 2011; Wolters, 2011). SRL consists of three cyclical phases (Zimmerman, 2000). In forethought phase; students analyse the learning task and reveal the learning purposes. In this process, they can get support from their instructor or their peers. In the performance phase; students use strategies to complete learning assignments and monitor their motivation to achieve the effectiveness of these strategies. In selfreflection phase; students assess their own performance in the learning task and the effectiveness of the strategies they use. These evaluations are expressed as a cyclical process of SRL because it affects students' future goals and plans (Zimmerman, 2008). In this sense, SRL in the FCM occurs with forethought phase in the OLE session, and performance and self-reflection phases are generally observed in the F2F session. Thus, Lai and Hwang (2016) suggested using different strategies to enhance SRL in FCM.

\section{Self-regulated Learning Strategies}

Students need SRL strategies to complete the tasks assigned to them, to be able to work on their own, and to prepare for F2F sessions (Geduld, 2016). SRL has cognitive, metacognitive, and behavioural dimensions. According to Ning and Downing (2015); cognitive dimension includes rehearsing, organizing and elaborating strategies for learning information; metacognitive dimension includes goal setting and self-evaluation strategies to monitor the learning process; and 
behavioural dimension includes time management, note taking and testing. While cognitive strategies are required to process, transform, and organize knowledge, metacognitive strategies are important for planning, monitoring, and evaluating learning (Karlen, 2016). In line with this; Zimmerman and Martinez-Pons (1988) describe metacognitive, motivational, and behavioural strategies of SRL. Metacognitive strategies; goal setting and planning, organizing and transforming, seeking information, rehearsing and memorizing, motivational strategies; include strategies for developing intrinsic interest and self-efficacy, behavioural strategies include environmental structuring, keeping records and monitoring, reviewing texts, notes, exams, and seeking assistance from peers, instructors, other resources (Sebesta \& Speth, 2017). Pintrich (1999) similarly suggested a model of cognitive, metacognitive, resource management, and motivational strategies to improve SRL. Cognitive strategies in this model framework are rehearsing, elaborating, and organizing strategies. The rehearsing strategy is that the topics to be learned can be read or repeated after reading a piece of text. Elaborating strategies refer to summarize learned content, create an analogy, write notes, and answer the questions. Organizing strategies include understanding and expressing the main idea of the course content, distinguishing important parts of a text. Metacognitive strategies are planning, monitoring and regulating strategies. Planning strategies include determining the purpose for learning, producing questions about the topic to be learned and analysing it. Monitoring strategies include controlling the learner's own learning process, recognizing its deficiencies and managing time. Regulating strategies are closely linked to monitoring strategies. It is the ability of students to repeat the topics that they cannot understand during the learning process or to continue their performance when they face more difficult tasks. Resource management strategies include control and management of the environment. It is the aim of the students to get help from their peers or instructor and to check their efforts to learn. With a different perspective, Barnard-Brak, Paton, and Lan (2010) explained that the forethought phase of SRL can be used for strategies of structuring the environment and goal setting. Time management strategies, task strategies, and help seeking strategies can be utilized in performance phase of SRL and self-evaluation strategy can be used in the self-reflection phase.

Overall, it is thought that these strategies can be considered as cognitive, metacognitive, behavioural and motivational strategies in general, although there are different evaluations of SRL strategies. These strategies are being utilized by students especially when SRL are thought for making improvements in forethought, performance and self-reflection phases. Cognitive strategies like rehearsing of metacognitive strategies such as goal setting and planning and monitoring are used for the forethought phase. Behavioural strategies such as taking notes and testing can also be used. For the performance phase, cognitive strategies such as elaborating and organizing can be used, as well as metacognitive strategies such as monitoring, and regulating. In addition, while behavioural strategies such as taking notes, getting help, time management and testing are used, motivational strategies are utilized by giving feedback to increase the intrinsic interest and selfefficacy of the students. Metacognitive strategies such as the evaluation of the learning process during the self-reflection phase can be utilized. Students with SRL can identify their own learning goals, use different learning strategies, and know their strengths and weaknesses (Pintrich, 2000). Many studies have shown that SRL strategies have a positive effect on students' academic 
performance and perceptions. For instance; Yang, Chen, and Chen (2018) conducted a study in mathematics course with 60 high school students. Table 1 shows the studies using SRL strategies for different learning environments. At the end of the study, SRL was found to increase the performance of students. They presented various for three phases of SRL. They created goal setting tool for the students regularly to write their goals. They suggested strategic planning tool to share their planning and strategies to learn the content of the course. While online quiz tool is used to test their performances every week, self-reflection tool is used to compare the performance they expected with their current performance. In addition, students evaluated their satisfaction and reflected how to enhance their performances with self-reflection tools. In another study, the researchers carried out a study with 4831 online learner. The effects of SRL strategies on students' behavior and goal attainment were investigated. At the end of the study, it was revealed that goal setting and strategic planning strategies could predict students' behaviors and goal attainment (Kizilcec, Perez-Sanagustín, \& Maldonado, 2017). Sletten (2017) was carried out with 76 students in the biology course designed with FCM. As a result, it was revealed that SRL strategies positively affect students' perceptions. Another study focusing on the EFL context investigated the relationship between the use of SRL strategies and the success of EFL. At the end of the study, it was found out that the students were able to use their SRL strategies to relate their EFL successes (Şeker, 2016). Another EFL study examined the relationship between foreign language classroom anxiety and self-regulated learning strategies. A negative relationship between students' use of SRL strategies and foreign language classroom anxiety has emerged (Martirossian \& Hartoonian, 2015). Wilson and Narayan (2014) with 96 students in blended learning environment revealed that there was a relationship between students' use of SRL strategies and their academic performance. They used pproject based activities in which students have uploaded the project files to the system for organising strategy. They also used discussion forum components in order to help seek and feedback. Students were allowed self-evaluation tools to assess their performance.

In sum, it is seen that; studies in online learning; SRL strategies are used both in the online learning environment and in the face-to-face learning environment designs and using SRL strategies improve students' academic performance in EFL and other courses. Considering the skills and knowledge in EFL courses in this study, a design for EFL course is presented by examining the different studies using SRL strategies.

\section{Need for the Study}

In recent years, FCM has begun to be applied in EFL course (Evseeva \& Slozhenko, 2015; Egbert et al., 2015; Alsowat, 2016; Huang \& Hong, 2016; Chen-Hisieh et al., 2016). In addition to the contributions made to the learning performances of the EFL courses designed with the FCM, there are also some design-based limitations. One of these limitations is that students with low SRL do not perform activities in OLE and F2F sessions and cannot take responsibility for learning. Since both the FCM and the innovative foreign language teaching methods are student-centred, it is expected that students in the EFL course designed with the FCM will have a certain level of SRL (Butzler, 2016). Namely, the EFL course based on FCM can negatively affect the learning 
performance of students with low SRL (Şeker, 2016; Martirossian \& Hartoonian, 2015; Abbasian \& Hartoonian, 2014).

\section{Suggested FCM Model for EFL Courses: FCM-EFL}

Although SRL is not a new concept, it is a phenomenon that researchers still work theoretically and practically about it. SRL has a multidimensional structure that is explained with the cognitive, motivational and behavioural dimensions in various models (Karlen, 2016). Table 1 shows the commonly known SRL models.

Table 1. Commonly known SRL models

\begin{tabular}{|c|c|c|c|c|}
\hline SRL models & \multicolumn{4}{|c|}{ Phases in the model } \\
\hline $\begin{array}{l}\text { Winne and } \\
\text { Hadwin (1998) }\end{array}$ & $\begin{array}{l}\text { Defining the } \\
\text { Task }\end{array}$ & $\begin{array}{l}\text { Setting Goals } \\
\text { and Planning }\end{array}$ & Enacting Tactics & $\begin{array}{l}\text { Adapting } \\
\text { Metacognition }\end{array}$ \\
\hline $\begin{array}{l}\text { Zimmerman } \\
(2000)\end{array}$ & Forethought & & Performance & Self-reflection \\
\hline Pintrich (2000) & $\begin{array}{l}\text { Forethought, } \\
\text { Activation }\end{array}$ & lanning and & Monitoring Control & $\begin{array}{l}\text { Reaction and } \\
\text { Reflection }\end{array}$ \\
\hline
\end{tabular}

As seen in Table 1, although SRL is explained in various phases, SRL can be considered as a model that includes the common phases of forethought, performance and self-reflection (Zeidner \& Stoeger, 2019). SRL models are suggested to be adapted for F2F and OLE sessions of FCM (Greene et al., 2011). Lai and Hwang (2016) examined the effect of self-regulatory FCM on primary school students' academic achievement in mathematics class. They designed a self-regulated learning environment for out-of-class activities by adapting SRL phases to FCM. The study concluded that the self-regulated FCM significantly improved the academic achievement of the students. Zheng, Ward, and Stanulis (2020), in their study with medical faculty students, determined SRL strategies students used in FCM within three-stage phase model. They found that, the students were able to use SRL strategies in the forethought and reflection phase, but they had problems in monitoring their own learning. In another study, Ng (2018) examined whether FCM designed with SRL principles is an effective pedagogy for university students. Students were able to get help from their peers through group work in the F2F session and they were allowed to get instant feedback from peers and the instructor. At the end of the study, found flexible learning opportunities in OLE. However, it was observed that they experienced interaction problems with their peers and instructors in the F2F session. This led to the need for consideration of additional SRL principles. Another study examined the effect of self-regulated FCM on the language proficiency of university students in EFL course. A self-monitoring system was established by using goal setting and selfassessment strategies for students in OLE environments (Abe et al., 2018). The results showed that FCM can be an effective learning tool in EFL courses.

The previous studies about SRL in FCM suggest strong enthusiasm among researchers that; the focus is on OLE designs, where the control and supervision of students is more difficult than the F2F learning environment. In this study, FCM's SRL strategies for OLE and F2F sessions were planned and implemented separately for the forethought, performance and self-reflection phases. Thus we suggest a design model for implementing FCM for university students including SRL 
strategies in EFL course. The model is more appropriate for students who are taking the EFL course for the first time. We think implementing this model can improve the performance of the students via managing their SRL. Figure 2 presents the theoretical framework followed in the suggested model.

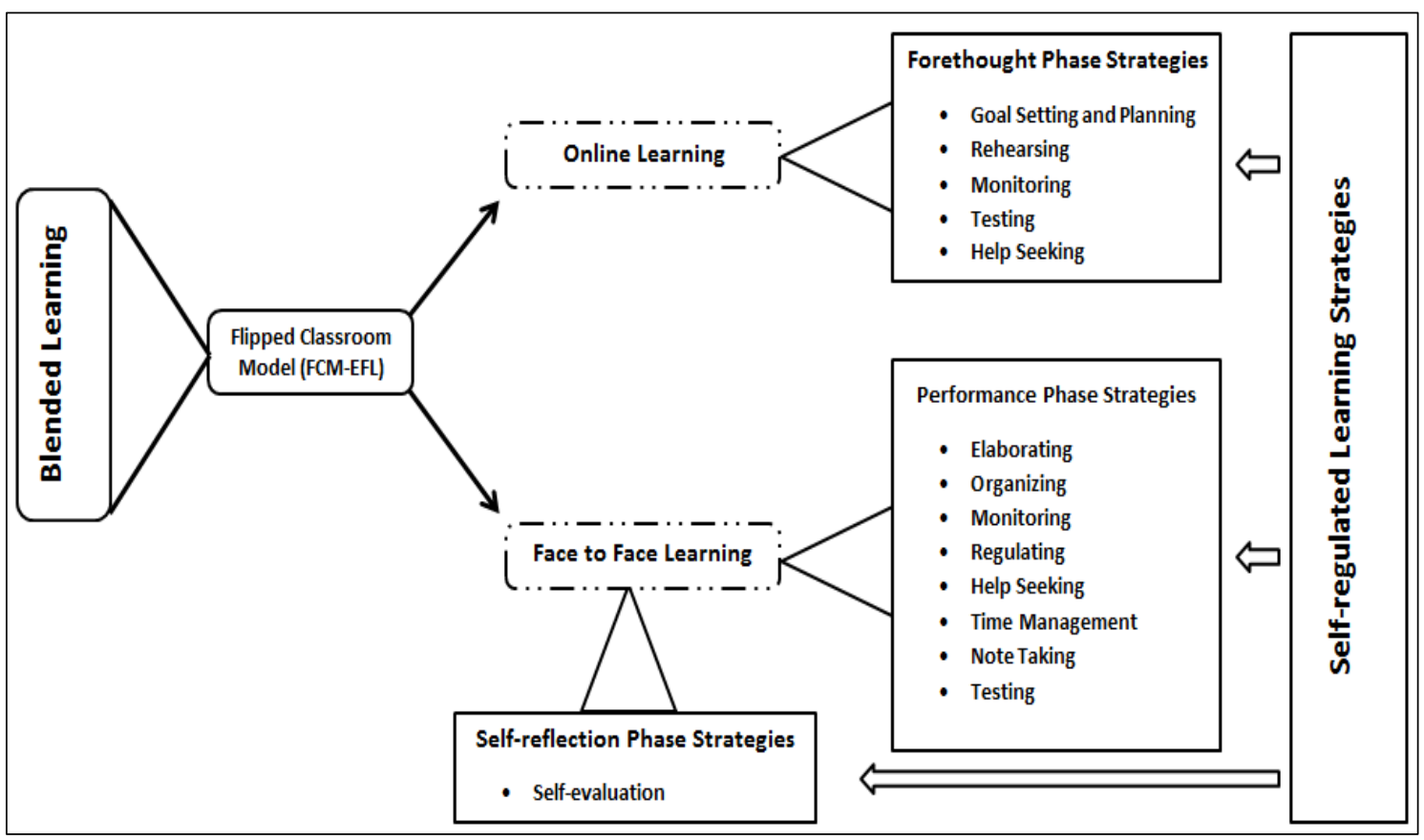

Figure 2. Theoretical framework followed in suggested model

Since the model includes two main sessions (OLE, FCM), the following sections are structured through these sessions.

\section{Online Learning Environment (OLE) Session}

In the FCM, forethought phase of SRL is complemented by activities at home. Students use the OLE to conduct activities at home and prepare for F2F sessions. An online learning platform is designed using SRLs so that students construct knowledge. The online sessions can be designed within LMSs having basic components.

Figure 3 shows the components of the online learning platform. 


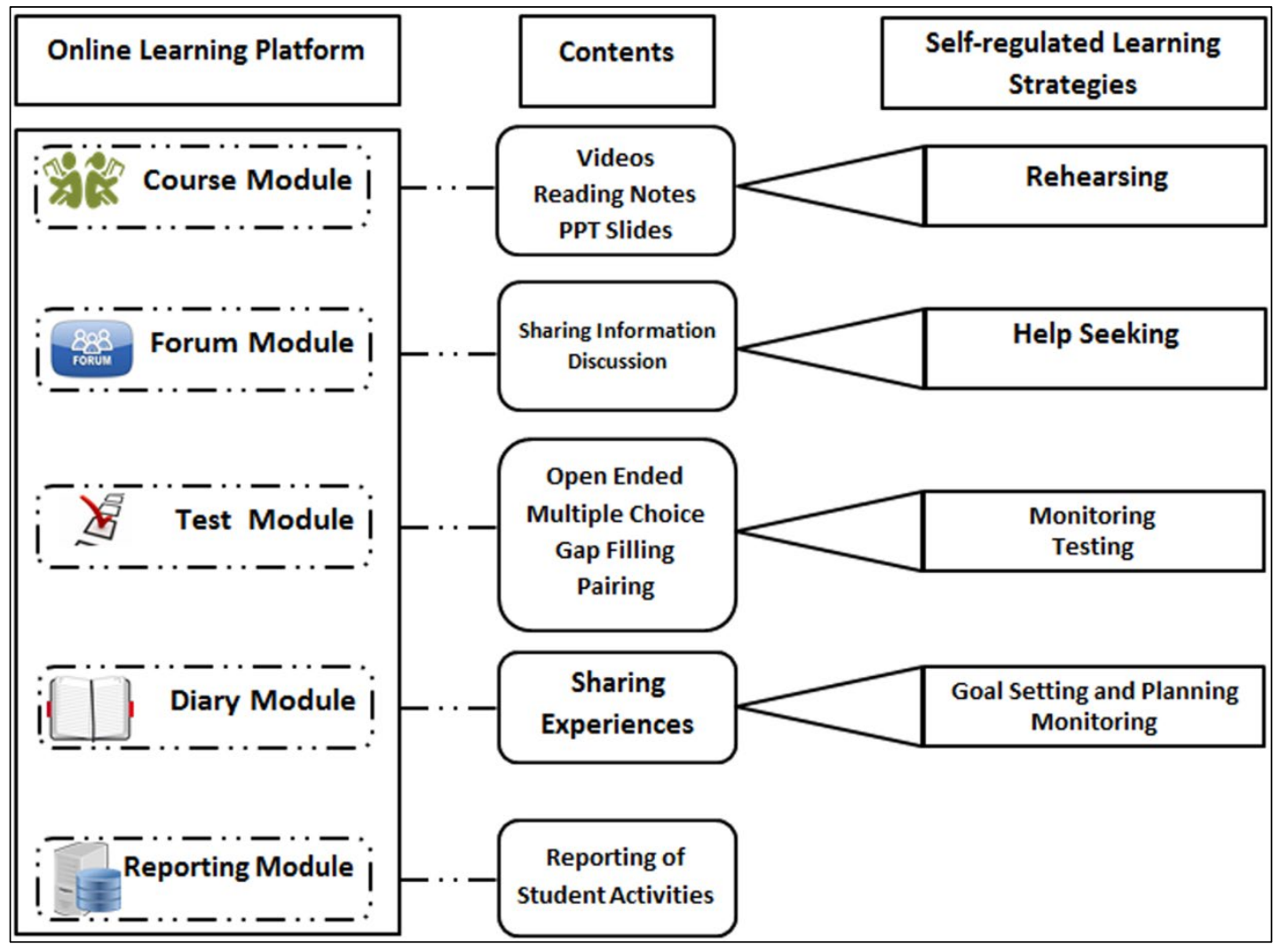

Figure 3. SRL strategies integrated with online learning session

In EFL courses, students can find opportunity to practice grammar skills in the F2F learning environment which they acquired in the online platform, and they can follow the content without considering time or space in the course module (Rehearsing). If they do not understand the content, they can search the necessary support from the forum module. Also, instructor or their peers can ask for help (Help Seeking). They use the test module to notice students' deficiencies in the learning process (Monitoring and Testing). Students who fail in the test module are encouraged to watch again their video content and redo the tests. Students by writing their goals and plans for the F2F course in the diary module every week may exhibit the goal setting and planning. On the other hand, they are asked to share their experiences, deficiencies and criticisms in the OLE (Monitoring). Thus, students are aimed to control and monitor their own learning process.

Within the model, the instructor can examine the reporting module before coming to the F2F learning environment. Reporting module can report the video monitoring rate of students, online test achievement score, forum module and daily module shares. Thus, the instructor can identify and encourage students who do not complete the activities.

\section{Face to Face Learning (F2F) Session}

The performance and self-reflection phase of self-regulated learning in the FCM is complemented by activities in the F2F session. F2F session activities are also designed with SRL strategies. In addition, students are divided into collaborative groups to prepare writing and speaking activities. Figure 4 presents the activities of the F2F session. 


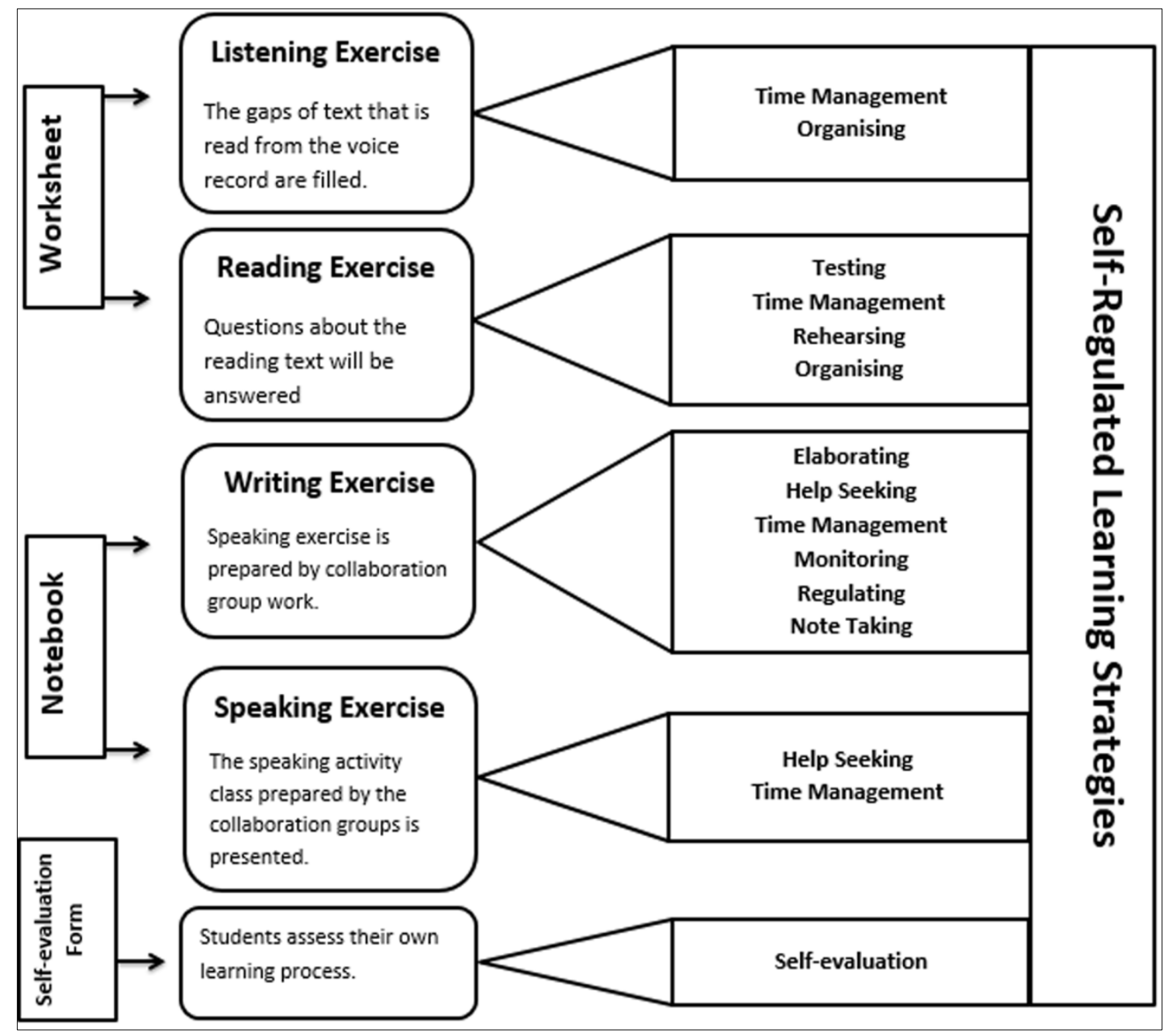

Figure 4. Face to face session activities

Listening, writing, reading and speaking activities can be easily integrated in the F2F session. Students are given a certain amount of time for each activity. If students do not complete the activities during this period, extra time may be granted. Reading is allocated for listening and reading activities. However, some places in the reading part are left blank. Students fill in the blanks for a certain period of time by ensuring that the reading part is listened through the speaker (Time management). Thus, students are expected to address the important parts of the voicerecorded text (Organizing). Testing multiple-choice, true-false and open-ended questions about the reading after the listening activity is completed. The reading parts are organized to include the topics covered the previous week (Rehearsing). On the other hand, students can prepare for writing and speaking at the same time. The students can work on the speaking activity for the topic covered during the week by using the notebook (Elaboration). The speaking activity contains real situations. Hence, students can get help from peers, instructor and the internet while they are preparing for the activity (Help seeking). Students are expected to prepare a speaking activity within a certain time period (Time management). In this process, students can correct the errors (Monitoring and Regulating) as well as use their previous knowledge. In addition, the instructor gives feedback to the students and takes notes on the topic (Note taking and Feedback). Then, collaborative groups present their speaking activity to other groups. At the end of all these activities, 
students are given a self-evaluation form to evaluate their own learning process (Self-evaluation). This allows students to take on their learning responsibilities and get ideas about their current situation for future learning.

\section{Conclusion and Recommendations}

The FCM model suggested in this study shows that communication-based learning environments can be created in the EFL course designed within SRL strategies. While these environments are being created, SRL strategies are utilized. The rehearsing strategy is used to provide unlimited repetition of course module contents. Through the forum module, the help seeking strategy is utilized by providing academic and technical support to the instructor and peers of the students. The testing module allows students to check their own learning and put forward testing and monitoring strategies. Goal setting and planning strategies are leveraged by encouraging the diary modules to share their experiences in the OLE and goals for the F2F learning environment.

In the F2F session of the suggested FCM model; listening, reading, writing and speaking activities, which are the basic skills in EFL course, are supported. The worksheet is distributed to students for listening and reading activities and a certain time period is given for each activity completion within the framework of time management strategy. In this regard, worksheets are prepared for each course so that students could organize and manage their learning process. The reading activity is prepared to include the repetition of previous topics with the rehearsing strategy. Additionally, writing and speaking activities are started after the listening and reading activity is completed. Students prepare a speaking activity over real situations. Moreover, elaborating and help seeking strategies are used in this process as the activities are prepared through collaborative group work. The instructor is allowed to provide feedback to the students in this process, enabling them to recognize their deficiencies and mistakes. Thus, monitoring, regulating and note taking strategies are used. In addition, speaking activities are presented by cooperative groups to the others in the class. These speaking activities consist of dialogues and all members of the group have a role in the activity. While this event is being organized, students are provided with peer and instructor support. At the end of each course, students also evaluate their activities in the OLE and the F2F learning environment through a self-evaluation form.

To conclude, the suggested model indicates that SRL strategies can be integrated within the framework of the FCM, including the online and F2F learning sessions. In this way, a design has been put forward which enables the activities necessary for the EFL teaching; listening, reading, writing and speaking skills to be acquired. In this model, the rehearsing strategy in the course module and the help seeking strategy in the forum module can be applied for OLE activities. The diary module can be used for goal setting and planning strategies while monitoring and testing strategies are utilized in the test module. The design within the framework of SRL strategies is addressed separately for online and F2F learning environments.

In this study, SRL strategies are considered in relation to both FCM and foreign language skills. Thus, associating the skills in these two can be considered applicable. One can also integrate different SRL strategies to be utilized in the OLE and the F2F sessions. The links between the 
features of FCM and SRL can be based on the skills to be acquired. Activities can be designed where students are active, take responsibility and can organize their own learning process. The model can be implemented for some other courses including communication based structure such as foreign language courses in future research.

\section{References}

1. Abbasian, G. R., \& Hartoonian, A. (2014). Using Self-Regulated Learning Strategies in Enhancing Language Proficiency with a Focus on Reading Comprehension. English Language Teaching, 7(6), 160-167.

2. Abe, Y., Hood, M., \& Elwood, J. (2018). Self-regulated Learning and Culture in the Flipped EFL Classroom with ICT. Journal of JSEE, 66(5), 5_62-5_68.

3. Alsowat, H. (2016). An EFL flipped classroom teaching model: effects on English language higher-order thinking skills, student engagement and satisfaction. Journal of Education and Practice, 7(9), 108-121.

4. Al-Zahrani, A. M. (2015). From passive to active: The impact of the flipped classroom through social learning platforms on higher education students' creative thinking. British Journal of Educational Technology, 46(6), 1133-1148.

5. Baepler, P., Walker, J. D., \& Driessen, M. (2014). It's not about seat time: Blending, flipping, and efficiency in active learning classrooms. Computers \& Education, 78, 227-236.

6. Barnard-Brak, L., Paton, V. O., \& Lan, W. Y. (2010). Profiles in self-regulated learning in the online learning environment. The International Review of Research in Open and Distributed Learning, 11(1), 61-80.

7. Bergmann, J., \& Sams, A. (2012). Flip your classroom. International Society for Technology in Education, 20.

8. Butzler, K. B. (2016). The synergistic effects of self-regulation tools and the flipped classroom. Computers in the Schools, 33(1), 11-23.

9. Chen-Hsieh, J. S., Wu, W. C. V., \& Marek, M. W. (2017). Using the flipped classroom to enhance EFL learning. Computer Assisted Language Learning, 30(1-2), 1-21.

10. Coyne, R. D., Lee, J., \& Denitsa, P. (2017). Re-visiting the flipped classroom in a design context. Journal of Learning Design, 10(2), 1-13.

11. Davies, R. S., Dean, D. L., \& Ball, N. (2013). Flipping the classroom and instructional technology integration in a college-level information systems spreadsheet course. Educational Technology Research and Development, 61(4), 563-580.

12. DeLozier, S. J., \& Rhodes, M. G. (2017). Flipped classrooms: a review of key ideas and recommendations for practice. Educational Psychology Review, 29(1), 141-151.

13. Djamàa, S. (2020). Lecture in the Living Room, Homework in the Classroom: The Effects of Flipped Instruction on Graduate EFL Students' Exam Performance. Computers in the Schools, 1-27. 
14. Egbert, J., Herman, D., \& Lee, H. (2015). Flipped instruction in English language teacher education: a design-based study in a complex, open-ended learning environment. Tesl-Ej, 19(2).

15. Elrayies, G. M. (2016). Flipped learning as a paradigm shift in architectural education. International Education Studies, 10(1), 93.

16. Engin, M., \& Donanci, S. (2016). Instructional videos as part of a 'flipped' approach in academic writing. Learning and Teaching in Higher Education: Gulf Perspectives, 13(1).

17. Ergen, B., \& Kanadli, S. (2017). The Effect of Self-Regulated Learning Strategies on Academic Achievement: A Meta-Analysis Study. Eurasian Journal of Educational Research, 69, 55-74.

18. Evseeva, A., \& Solozhenko, A. (2015). Use of flipped classroom technology in language learning. Procedia-Social and Behavioral Sciences, 206, 205-209.

19. Geduld, B. (2016). Exploring differences between self-regulated learning strategies of high and low achievers in open distance learning. Africa Education Review, 13(1), 164-181.

20. Giannakos, M. N., Chorianopoulos, K., \& Chrisochoides, N. (2015). Making sense of video analytics: Lessons learned from clickstream interactions, attitudes, and learning outcome in a video-assisted course. The International Review of Research in Open and Distributed Learning, 16(1).

21. Gilboy, M. B., Heinerichs, S., \& Pazzaglia, G. (2015). Enhancing student engagement using the flipped classroom. Journal of Nutrition Education and Behavior, 47(1), 109-114.

22. Greene, J. A., Robertson, J., \& Costa, L. J. C. (2011). Assessing self-regulated learning using think-aloud methods. Handbook of self-regulation of learning and performance, 313-328.

23. Hamdan, N., McKnight, P., McKnight, K., \& Arfstrom, K. M. (2013). The flipped learning model: a white paper based on the literature review titled 'a review of flipped learning'. Arlington, VA: Flipped Learning Network.

24. Hotle, S. L., \& Garrow, L. A. (2015). Effects of the traditional and flipped classrooms on undergraduate student opinions and success. Journal of Professional Issues in Engineering Education and Practice, 142(1).

25. Huang, Y. N., \& Hong, Z. R. (2016). The effects of a flipped English classroom intervention on students' information and communication technology and English reading comprehension. Educational Technology Research and Development, 64(2), 175-193

26. Hung, H. T. (2015). Flipping the classroom for English language learners to foster active learning. Computer Assisted Language Learning, 28(1), 81-96.

27. Järvelä, S., \& Järvenoja, H. (2011). Socially constructed self-regulated learning and motivation regulation in collaborative learning groups. Teachers College Record, 113(2), 350-374.

28. Kakosimos, K. E. (2015). Example of a micro-adaptive instruction methodology for the improvement of flipped-classrooms and adaptive-learning based on advanced blendedlearning tools. Education for Chemical Engineers, 12, 1-11. 
29. Karlen, Y. (2016). Differences in students' metacognitive strategy knowledge, motivation, and strategy use: A typology of self-regulated learners. The Journal of Educational Research, 109(3), 253-265.

30. Kizilcec, R. F., Pérez-Sanagustín, M., \& Maldonado, J. J. (2017). Self-regulated learning strategies predict learner behavior and goal attainment in Massive Open Online Courses. Computers \& Education, 104, 18-33.

31. Lai, C. L., \& Hwang, G. J. (2016).A self-regulated flipped classroom approach to improving students' learning performance in a mathematics course. Computers \& Education, 100, 126140.

32. Love, B., Hodge, A., Grandgenett, N., \& Swift, A. W. (2014). Student learning and perceptions in a flipped linear algebra course. International Journal of Mathematical Education in Science and Technology, 45(3), 317-324.

33. Martirossian, A., \& Hartoonian, A. (2015). Lowering foreign language anxiety through selfregulated learning strategy use. English Language Teaching, 8(12), 209.

34. McLaughlin, J. E., Roth, M. T., Glatt, D. M., Gharkholonarehe, N., Davidson, C. A., Griffin, L. M., ... \& Mumper, R. J. (2014). The flipped classroom: a course redesign to foster learning and engagement in a health professions school. Academic Medicine, 89(2), 236-243.

35. Mehring, J. (2016). Present research on the flipped classroom and potential tools for the EFL classroom. Computers in the Schools, 33(1), 1-10.

36. Moos, D. C., \& Bonde, C. (2016). Flipping the Classroom: Embedding Self-Regulated Learning Prompts in Videos. Technology, Knowledge and Learning, 21(2), 225-242.

37. Ning, H. K., \& Downing, K. (2015). A latent profile analysis of university students' selfregulated learning strategies. Studies in Higher Education, 40(7), 1328-1346.

38. Ng, E. M. (2018). Integrating self-regulation principles with flipped classroom pedagogy for first year university students. Computers \& Education, 126, 65-74.

39. Özdamli, F., \& Asiksoy, G. (2016). Flipped Classroom Approach. World Journal on Educational Technology: Current Issues, 8(2), 98-105.

40. Pintrich, P. R. (1999). The role of motivation in promoting and sustaining self-regulated learning. International Journal of Educational Research, 31(6), 459-470.

41. Pintrich, P. R. (2000). The role of goal orientation in self-regulated learning. In M. Boekaerts, P. Pintrich, \& M. Zeidner (Eds.), Handbook of self-regulation (pp. 451-502). San Diego, CA: Academic Press.

42. Roehl, A., Reddy, S. L., \& Shannon, G. J. (2013). The flipped classroom: an opportunity to engage millennial students through active learning strategies. Journal of Family and Consumer Sciences, 105, 44-49.

43. Sebesta, A. J., \& Speth, E. B. (2017). How should 1 study for the exam? Self-regulated learning strategies and achievement in introductory biology. CBE-Life Sciences Education, 16(2), a30. 
44. Şeker, M. (2016). The use of self-regulation strategies by foreign language learners and its role in language achievement. Language Teaching Research, 20(5), 600-618.

45. Shahnaz, S. M. F., \& Hussain, R. M. R. (2016). Designing Instruction for Active and Reflective Learners in the Flipped Classroom. Malaysian Journal of Learning and Instruction, 13(2), 147173.

46. Shih, H. C. J., \& Huang, S. H. C. (2019). College students' metacognitive strategy use in an EFL flipped classroom. Computer Assisted Language Learning, 1-30.

47. Sletten, S. R. (2017). Investigating flipped learning: Student self-regulated learning, perceptions, and achievement in an introductory biology course. Journal of Science Education and Technology, 26(3), 347-358.

48. Su Ping, R. L., Verezub, E., Adi Badiozaman, I. F. B., \& Chen, W. S. (2020). Tracing EFL students' flipped classroom journey in a writing class: Lessons from Malaysia. Innovations in Education and Teaching International, 57(3), 305-316.

49. Turan, Z., \& Akdag-Cimen, B. (2020). Flipped classroom in English language teaching: a systematic review. Computer Assisted Language Learning, 33(5-6), 590-606.

50. Wanner, T., \& Palmer, E. (2015). Personalising learning: Exploring student and teacher perceptions about flexible learning and assessment in a flipped university course. Computers \& Education, 88, 354-369.

51. Wilson, K., \& Narayan, A. (2016). Relationships among individual task self-efficacy, selfregulated learning strategy use and academic performance in a computer-supported collaborative learning environment. Educational Psychology, 36(2), 236-253.

52. Wolters, C. A. (2011). Regulation of motivation: Contextual and social aspects. Teachers College Record, 113(2), 265-283.

53. Wu, W. C. V., Hsieh, J. S. C., \& Yang, J. C. (2017). Creating an online learning community in a flipped classroom to enhance EFL learners' oral proficiency. Journal of Educational Technology \& Society, 20(2), 142-157.

54. Yang, T. C., Chen, M. C., \& Chen, S. Y. (2018). The influences of self-regulated learning support and prior knowledge on improving learning performance. Computers \& Education, $126,37-52$.

55. Zainuddin, Z., \& Halili, S. H. (2016). Flipped classroom research and trends from different fields of study. The International Review of Research in Open and Distributed Learning, 17(3).

56. Zeidner, M., \& Stoeger, H. (2019). Self-Regulated Learning (SRL): A guide for the perplexed. High Ability Studies, 30(1-2), 9-51.

57. Zheng, B., Ward, A., \& Stanulis, R. (2020). Self-regulated learning in a competency-based and flipped learning environment: learning strategies across achievement levels and years. Medical Education Online, 25(1), 1686949. 
58. Zhonggen, Y., \& Guifang, W. (2016). Academic Achievements and Satisfaction of the ClickerAided Flipped Business English Writing Class. Journal of Educational Technology \& Society, 19(2).

59. Zimmerman, B. J. (2000). Attainment of self-regulation: A social cognitive perspective. In M. Boekaerts, P. R. Pintrich, \& M. Zeidner (Eds.), Handbook of self-regulation (pp. 13-39). San Diego, CA: Academic Press.

60. Zimmerman, B. J. (2008). Investigating self-regulation and motivation: Historical background, methodological developments, and future prospects. American Educational Research Journal, 45(1), 166-183.

61. Zimmerman, B. J., \& Martinez-Pons, M. (1988). Construct validation of a strategy model of student self-regulated learning. Journal of Educational Psychology, 80(3), 284.

62. Zumbrunn, S., Tadlock, J., \& Roberts, E. D. (2011). Encouraging self-regulated learning in the classroom: A review of the literature. Metropolitan Educational Research Consortium (MERC). 